\title{
Mengukur Pengetahuan Investasi Para Mahasiswa Untuk Pengembangan Galeri Investasi Perguruan Tinggi
}

\author{
Mumuh Mulyana ${ }^{1}$ Lukman Hidayat² ${ }^{\text {Ratih }}$ Puspitasari $^{3}$
}

\begin{abstract}
ABSTRAK
Galeri Investasi Perguruan Tinggi terus dikembangkan di berbagai Kampus. Sebagai bagian dari Pengembangan Galeri Investasi, peningkatan pemahaman mahasiswa sebagai calon investor terkait pengetahuan investasi perlu pula dilakukan. Tujuan penelitian ini adalah mengukur pemahaman mahasiswa tentang Pengetahuan Pasar Modal, Pengetahuan Jenis Instrumen Investasi, Pengetahuan Tingkat Keuntungan Investasi, Pengetahuan Tingkat Risiko Investasi dan Pengetahuan Dasar Penilaian Saham. Penelitian dilakukan bulan Mei - Juli 2019 kepada 200 orang Mahasiswa Anggota Galeri Investasi STIE Kesatuan Bogor. Hasil penelitian menunjukkan masih belum optimalnya pemahaman mahasiswa tentang Pengetahuan Investasi di Pasar Modal (pemahaman kategori baik). Hal yang belum dipahami dengan baik adalah tentang Pihak yang memiliki Kelebihan Dana antara Masyarakat atau Perusahaan, Tempat Memperoleh Saham, masih bercampurnya konsep keuntungan yang diperoleh instrumen investasi di pasar modal dan perbankan, dan bentuk risiko investasi saham berupa tidak mendapatkan dividen dan kemungkinan bangkrut bagi perusahaan yang telah go public.
\end{abstract}

Kata Kunci: pengetahuan investasi, galeri investasi perguruan tinggi, mahasiswa, pasar modal

\section{PENDAHULUAN}

Pertumbuhan investor saat ini masih dikatakan sangat rendah jika dibandingkan dengan jumlah penduduk Indonesia. Aktivitas investasi masih dipandang sebagai hal yang relatif baru bagi masyarakat. Dibandingkan dengan Negara lain, animo masyarakat Indonesia untuk berinvestasi terbilang masih cukup rendah yaitu berjumlah 0,15\% penduduk Indonesia (Pajar, 2017). Di sisi lain, dalam rangka menjaga eksistensi dan menumbuhkembangkan pasar modal, diperlukan adanya kekuatan basis investor domestik dan ketersediaan investasi jangka panjang. Nilai investasi yang besar apabila hanya dimiliki oleh sedikit pihak kurang mendukung peningkatan basis investor domestik, sebagaimana dinyatakan dalam Master Plan Pasar Modal Indonesia 20102014.

Merespon kondisi ini, Bursa Efek Indonesia (BEI) dan Otoritas Jasa Keuangan (OJK) melakukan program edukasi (Ferlina dan Riswan, 2017). Salah satu yang menjadi objek sasaran utama PT Bursa Efek Indonesia dalam menjaring investor-investor baru

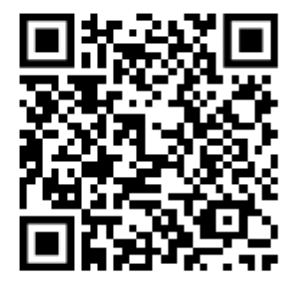

1. Program Studi D3

Manajemen Pemasaran,

Sekolah Tinggi IImu Ekonomi Kesatuan, Jalan

Ranggagading No. 1 Bogor, Jawa Barat 16123 Indonesia

2. Program Studi Manajemen, Sekolah Tinggi IImu Ekonomi Kesatuan, Jalan

Ranggagading No. 1 Bogor, Jawa Barat 16123 Indonesia

\section{EMail}

mumuh.mulyana@stiekesatu an.ac.id

Submitted : Juli 2019

Accepted : Juli 2019

JAS-PT

JURNAL ANALISIS SISTEM PENDIDIKAN TINGGI ISSN $2580-5339$ eISSN $2620-5718$

Volume 3

Nomor 1

JULI 2019

Hal $31-52$

FORUM DOSEN INDONESIA 
adalah dengan mendirikan galeri investasi yang ada di setiap Perguruan Tinggi. Galeri investasi merupakan salah satu sarana pembelajaran yang dapat menjadi sebuah kekuatan untuk mencerdaskan bangsa. Tujuan pendirian galeri investasi untuk kalangan akademi adalah sosialisasi, edukasi dan sejauh mana mahasiswa mampu mempraktekkan teori yang dipelajari dalam perkuliahan serta mendukung kegiatan penelitian.

Tabel 1. Komposisi Investor Berdasarkan Populasi Penduduk

\begin{tabular}{lccc}
\hline Negara & $\begin{array}{c}\text { Jumlah } \\
\text { Penduduk (Juta) }\end{array}$ & $\begin{array}{c}\text { Jumlah } \\
\text { Investor (Juta) }\end{array}$ & $\begin{array}{c}\text { Persentase Investor Pasar Modal } \\
\text { Dibanding Jumlah Penduduk }\end{array}$ \\
\hline Singapura & 5.08 & 3.05 & $60.00 \%$ \\
Hongkong & 7.00 & 1.23 & $17.50 \%$ \\
Malaysia & 28.90 & 3.61 & $12.50 \%$ \\
Korsel & 49.10 & 4.17 & $8.50 \%$ \\
Jepang & 127.53 & 10.20 & $8.00 \%$ \\
Indonesia & 238.00 & 0.33 & $0.14 \%$
\end{tabular}

Sumber: Situmorang, 2014

Mahasiswa dapat menjadi potensi besar sebagai investor pada pasar modal baru. Hal ini dapat terwujud dengan semakin bertambah banyaknya galeri investasi yang dibangun, dengan demikian jumlah investor baru dari kalangan mahasiswa juga semakin meningkat (Nicky Hogan dalam Sugianto, 2017). Komang dkk (2015) dan Hermanto (2017) mengatakan tidak bisa dipungkiri bahwa mahasiswa merupakan salah satu calon investor muda yang paling menarik karena telah memiliki dasar pengetahuan investasi yang diberikan sejak memasuki dunia perkuliahan.

Pengetahuan Investasi menjadi penting dimiliki calon investor sebelum melakukan investasi dengan mengeluarkan sejumlah dana atau sumber daya lainnya terhadap satu atau berbagai instrumen investasi. Halim (2005:4) menyatakan bahwa untuk melakukan investasi di pasar modal diperlukan pengetahuan yang cukup, pengalaman serta naluri bisnis untuk menganalisis efek-efek mana yang akan dibeli. Pengetahuan yang memadai sangat diperlukan untuk menghindari terjadinya kerugian saat berinvestasi di pasar modal, seperti pada instrumen investasi saham.

Rumusan Masalah penelitian ini adalah sebagai berikut :

1. Bagaimana Pengetahuan Pasar Modal yang dimiliki Mahasiswa?

2. Bagaimana Pengetahuan Jenis Instrumen Investasi yang dimiliki Mahasiswa?

3. Bagaimana Pengetahuan Tingkat Keuntungan dimiliki Mahasiswa?

4. Bagaimana Pengetahuan Tingkat Risiko yang dimiliki Mahasiswa?

5. Bagaimana Pengetahuan Dasar Penilaian Saham yang dimiliki Mahasiswa?

\section{TINJAUAN PUSTAKA}

\section{Galeri Investasi}

Galeri Investasi merupakan perpanjangan tangan dari Bursa Efek Indonesia (BEI).

JAS-PT

JURNAL ANALISIS SISTEM PENDIDIKAN TINGGI ISSN $2580-5339$ eISSN $2620-5718$

Volume 3

Nomor 1

JULI 2019

Hal $31-52$

FORUM DOSEN INDONESIA
Galeri Investasi didirikan atas kerjasama Perguruan Tinggi dengan Bursa Efek Indonesia. Karenanya sering disebut pula sebagai Pojok BEI. Alasan BEI melakukan kerjasama dengan Perguruan Tinggi adalah untuk meningkatkan investasi masyarakat di Pasar Modal, terutama terkait kemudahan aksesnya. BEI memandang Pasar modal memiliki peran penting dalam menunjang perekonomian suatu negara dikarenakan pasar modal memiliki dua fungsi sekaligus, yaitu fungsi ekonomi dan fungsi keuangan. Pasar modal ialah tempat dimana bertemunya antara pihak yang memiliki kelebihan 
dana (investor) dengan pihak yang membutuhkan dana (perusahaan) dengan cara memperjualbelikan sekuritas (Eduardus, dalam Verawati 2014).

\section{Investasi di Galeri Investasi}

Mahasiswa dapat mulai untuk berinvestasi di beberapa sektor salah satunya di pasar modal demi memiliki kondisi finansial yang lebih baik di masa depan. Sebagai mahasiswa, seringkali dana menjadi kendala utama dalam melakukan investasi terutama bagi mahasiswa yang mayoritas penghasilanya didapatkan dari kiriman orang tua. Jika dilihat secara umum, sumber keuangan mahasiswa bisa diperoleh dengan beberapa cara yakni (1) pemberian dari orang tua, (2) beasiswa, (3) uang yang berasal dari hadiah atau bonus, (4) dan yang terakhir berasal dari pendapatan pribadi/ pekerjaan sampingan yang dimiliki. Meski demikian, syarat dan ketentuan dalam membuka akun investasi di pasar modal saat ini terbilang sangat mudah. Di beberapa sekuritas saat ini, dana awal yang harus disetorkan untuk membuat account cukup yakni berkisar harga Rp100.000,00. Modal yang disetorkan ketika membuka account tidak harus dibelanjakan seluruhnya. Setelah proses pembukaan account selesai, kita dapat mentransfer kembali sebagian dari modal yang kita setor, dan menyisakan sejumlah yang ingin kita investasikan saja. Hal ini juga didukung dengan diterapkannya penurunan jumlah saham dari sebelumnya 500 lembar per lot menjadi 100 lembar per lot, sehingga bisa terjangkau mahasiswa. Dengan adanya kemudahan-kemudahan yang diberikan oleh pihak sekuritas tersebut diharapkan mampu memberikan motivasi dan minat bagi masyarakat untuk berinvestasi khususnya investasi di pasar modal.

\section{Pengetahuan Investasi}

Baihaqi (2016:230) menjelaskan pengetahuan adalah informasi yang telah diorganisasikan di dalam memori sebagai bagian dari sebuah system atau jaringan informasi yang terstruktur. Dengan kata lain pengetahuan adalah informasi yang telah diproses. Syahyunan (2015:1) menjelaskan investasi adalah komitmen atas sejumlah dana atau sumber daya lainnya yang dilakukan pada saat ini, dengan tujuan memperoleh keuntungan di masa yang akan datang. Dengan demikian dapat dinyatakan pengetahuan investasi adalah informasi yang telah diproses tentang komitmen mengalokasikan sumber daya untuk memperoleh keuntuntungan di masa mendatang sebagai imbalan atas waktu dan risiko terkait investasi tersebut.

\section{Pengetahuan Pasar Modal}

Pasar modal merupakan tempat diperjualbelikannya instrument keuangan jangka panjang seperti utang, ekuitas (saham), instrument derivative dan instrument lainnya. Pasar modal merupakan sarana pendanaan bagi perusahaan maupun institusi lain (misalnya pemerintah), dan sebagai sarana kegiatan berinvestasi (Darmadji dan Fakhruddin. 2012). Pengetahuan Pasar Modal merupakan pengetahuan tentang konsep dan manfaat keberadaan pasar modal di Indonesia yaitu: a. Menyediakan sumber pembiayaan (jangka panjang) bagi dunia usaha, b. Memberikan wahana investasi bagi investor, c. Menyediakan indikator utama bagi tren ekonomi negara, $d$. Memungkinkan penyebaran kepemilikan perusahaan hingga lapisan masyarakat menengah, e. Penciptaan iklim usaha yang sehat, f. Menciptakan lapangan kerja, g. Memberikan kesempatan memiliki perusahaan yang sehat dan mempunyaiprospek, $h$. Menjadi alternatif investasi yang memberikan potensi keuntungan dengan resiko yang bisa di perhitungkan melalui keterbukaan, likuiditas, dan diversifikasi investasi, i. Membina iklim keterbukaan bagi dunia usaha, memberikan akses kontrol dunia social, dan j. Mendorong pengelolaan perusahaan dengan iklim keterbukaan dan pemanfaatan manajemen professional.

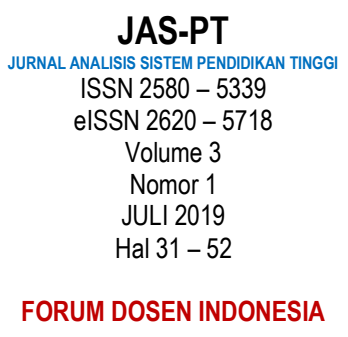




\section{Pengetahuan Jenis Instrumen Investasi}

Pengetahuan Jenis Instrumen Investasi merupakan pengetahuan tentang jenis investasi yang dapat dibedakan menjadi investasi langsung (direct investment) dan investasi tidak langsung (indirect investment). Investasi langsung adalah investasi pada aset atau faktor produksi untuk melakukan usaha (bisnis). Investasi langsung disebut juga sebagai investasi pada sektor rill atau investasi yang jelas wujudnya, mudah dilihat dan diukur dampaknya terhadap masyarakat secara keseluruhan. Investasi tidak langsung adalah investasi yang bukan pada aset atau factor produksi, tetapi pada aset keuangan (financial assets), seperti deposito, investasi pada surat berharga (sekuritas), seperti saham, obligasi, reksadana dan sebagainya.

\section{Pengetahuan Tingkat Keuntungan}

Tujuan berinvestasi adalah untuk mendapatkan keuntungan (Syahyunan 2015). Investasi yang diperoleh investor adalah investasi alternatif yang diharapkan dapat memberikan tingkat keuntungan yang paling tinggi. Namum kenyataannya tingkat keuntungan yang sesungguhnya diperoleh investor (actual return) tidak selalu sama dengan tingkat keuntungan yang diharapkan sebelumnya (expected return). Investor yang berinvestasi menghadapi risiko kemungkinan terjadinya penyimpangan tingkat keuntungan yang sesungguhnya dari tingkat keuntungan yang diharapkan.

Darmadji dan Fakhruddin (2015) menjelaskan ada dua keuntungan yang diperoleh investor dengan membeli atau memiliki saham yaitu: (1) Dividen yaitu pembagian keuntungan yang diberikan perusahaan penerbit saham tersebut atas keuntungan yang dihasilkan perusahaan. Dividen diberikan saat mendapat persetujuan dari pemegang saham dalam rapat umum pemegang saham (RUPS). Investor yang berhak menerima dividen adalah investor yang memegang saham hingga batas waktu yang ditentukan oleh perusahaan pada saat pengumuman dividen. Umumnya dividen merupakan salah satu daya tarik bagi pemegang saham jangka panjang. (2) Capital Gain yaitu selisih antara harga beli dan harga jual. Capital gain terbentuk dengan adanya aktivitas perdagangan saham di pasar sekunder. Umumnya investor dengan orientasi jangka pendek mengejar keuntungan melalui capital gain.

\section{Pengetahuan Tingkat Risiko}

Resiko adalah negative return dari suatu investasi. Dalam statistika, ukuran resiko adalah standar deviasi yang dihitung dari gejolak naik turunnya atau volatilitas harga. Semakin besar fluktuasi harga, semakin besar volatilitas, semakin besar debaran jantung investor sehingga semakin besar resiko (Syahyunan, 2013). Saham dikenal dengan karakteristik imbal hasil tinggi, resiko tinggi (high risk, high return). Artinya saham merupakan surat berharga yang memberikan peluang keuntungan tinggi namun juga berpotensi resiko tinggi (Darmadji dan Fakhruddin, 2015). Salah satu Resiko investor yang memiliki saham, adalah Perusahaan akan membagikan dividen jika operasinya menghasilkan keuntungan. Sebaliknya, perusahaan tidak dapat membagikan dividen jika perusahaan tersebut mengalami kerugian. Dengan demikian potensi kerugian investor untuk mendapatkan dividen ditentukan oleh kinerja perusahaan tersebut.

JAS-PT

JURNAL ANALISIS SISTEM PENDIDIKAN TINGG ISSN $2580-5339$ eISSN $2620-5718$

Volume 3

Nomor 1

JULI 2019

Hal $31-52$

FORUM DOSEN INDONESIA
Sikap investor terhadap risiko akan sangat tergantung kepada preferensi investor tersebut terhadap risiko. Investor yang lebih berani akan memilih investasi yang memiliki risiko tinggi, yang diikuti tingkat keuntungan yang tinggi pula. Sebaliknya investor yang tidak mau menanggung risiko yang terlalu tinggi, tentunya tidak akan bisa mengharapkan tingkat keuntungan yang terlalu tinggi (Syahyunan, 2015). Jenis investor dalam menghadapi risiko ada tiga: pertama, risk seeker, sikap seorang investor 
yang berani mengambil risiko. Investor yang demikian berani melakukan investasi meskipun tambahan risiko yang ditanggung lebih besar dari tambahan keuntungan. Kedua, indifferent to risk, yaitu sikap seorang investor yang tidak peduli terhadap risiko. Investor yang demikian bersedia untuk melakukan investasi berapa pun risikonya, walaupun tingkat keuntungan yang diharapkan tidak berubah. Ketiga risk averter, yaitu sikap seorang investor yang menghindari risiko. Investor tersebut hanya bersedia melakukan investasi jika tambahan keuntungan yang diharapkan lebih besar dari tambahan risiko.

\section{Pengetahuan Dasar Penilaian Saham}

Pengetahuan dasar penilaian saham merupakan pengetahuan investor terkait penilaian terhadap saham dengan menghitung NPV, IRR, dan lain-lain, pendapatan atau laba perusahaan yang diharapkan. Dalam penilaian saham dikenal adanya tiga jenis nilai yaitu nilai buku, nilai intrinsik dan nilai pasar. Uang dapat digunakan sebagai dasar dalam penilaian saham.

Dalam penilaian saham perlu digunakaan beberapa pendekatan-pendekatan dalam penilaian saham mulai dari: pendekatan nilai sekarang, pendekatan price eaning ratio (PER), pendekatan penilaian saham lainnya (rasio harga pasar/nilai buku, rasioharga saham/aliran kas, dan economic value added).

\section{METODOLOGI PENELITIAN}

Penelitian ini dilakukan di STIE Kesatuan Bogor terhadap mahasiswa yang tercatat sebagai mitra Galeri Investasi STIE Kesatuan. Penelitian berlangsung selama 3 bulan yaitu Mei - Juli 2019. Populasi dalam penelitian ini adalah mahasiswa Program Studi Akuntansi dan Manajemen Keuangan STIE Kesatuan Strata 1 yang berjumlah 200 orang mahasiswa (responden). Teknik analisis data yang digunakan dalam penelitian ini menggunakan distribusi frekuensi. Distribusi frekuensi adalah susunan data menurut kelas-kelas tertentu (Hasan, 2005). Distribusi frekuensi adalah pengelompokan data ke dalam beberapa kategori yang menunjukkan banyaknya data dalam setiap kategori, dan setiap data tidak dapat dimasukkan ke dalam dua atau lebih kategori (Suharyadi dan Purwanto, 2003). Pada tahap penyajian data, data yang sudah diklasifikasikan, disajikan atau ditampilkan dalam bentuk tabel atau grafik.

\section{HASIL DAN PEMBAHASAN}

\section{Karakteristik Responden}

Penelitian ini menggunakan data primer yang diperoleh langsung dari 200 orang responden yang merupakan mahasiswa yang menjadi Anggota Galeri Investasi STIE Kesatuan.

\section{Tabel 2 Data Lembar Kuesioner}

\begin{tabular}{lc}
\hline \multicolumn{1}{c}{ Keterangan } & JUMLAH \\
\hline Jumlah Responden & 275 \\
Jumlah Kuesioner yang dibagikan & 275 \\
Jumlah Kuesioner yang diolah & 200
\end{tabular}

Sumber: Data Primer Diolah, 2019

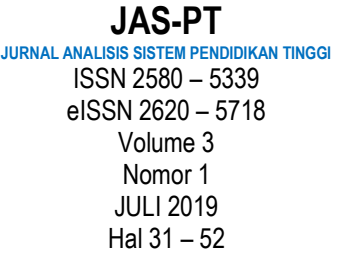


Responden penelitian ini didominasi oleh responden berjenis kelamin wanita yaitu sebesar $68 \%$, sisanya $32 \%$ adalah responden berjenis kelamin laki-laki. Secara umum, anggota Galeri Investasi STIE Kesatuan merupakan mahasiswa berjenis kelamin wanita. Usia mereka tersebar antara 18 tahun sampai dengan 26 tahun. Mayoritas berusia 20 tahun (46\%) dan 19 tahun (31.0\%). 119 orang responden merupakan mahasiswa yang berasal dari program studi Akuntansi - S1, sisanya sebanyak 40,5\% adalah mahasiswa program studi Manajemen Keuangan - S1. Untuk lebih lengkap tentang karakteristik responden dapat diperhatikan dalam Tabel 3.

Tabel 3. Sebaran Sampel Berdasarkan Karakteristik Responden

\begin{tabular}{|c|c|c|c|}
\hline \multicolumn{2}{|c|}{ Karakteristik Responden } & Frekuensi & $\%$ \\
\hline \multirow[t]{3}{*}{ Jenis Kelamin } & Laki-laki & 64 & 32.0 \\
\hline & Wanita & 136 & 68.0 \\
\hline & Total & 200 & 100 \\
\hline \multirow{10}{*}{ Usia } & 18 tahun & 2 & 1,0 \\
\hline & 19 tahun & 62 & 31,0 \\
\hline & 20 tahun & 92 & 46,0 \\
\hline & 21 tahun & 29 & 14,5 \\
\hline & 22 tahun & 5 & 2,5 \\
\hline & 23 tahun & 7 & 3,5 \\
\hline & 24 tahun & 1 & 0,5 \\
\hline & 25 tahun & 1 & 0,5 \\
\hline & 26 tahun & 1 & 0,5 \\
\hline & Total & 405 & 100 \\
\hline \multirow[t]{10}{*}{ Kelas } & $4 \mathrm{MK}$ A P & 25 & 12,5 \\
\hline & 4 MK B P & 9 & 4,5 \\
\hline & $4 \mathrm{MK} C \mathrm{P}$ & 11 & 5,5 \\
\hline & 4 MK D P & 11 & 5,5 \\
\hline & $4 \mathrm{MK} \mathrm{AK}$ & 25 & 12,5 \\
\hline & 4 AK A P & 38 & 19,0 \\
\hline & 4 AK B P & 25 & 12,5 \\
\hline & 4 AK C P & 29 & 14,5 \\
\hline & 4 AK D P & 27 & 13,5 \\
\hline & Total & 200 & 100 \\
\hline \multirow[t]{3}{*}{ Semester } & 4 & 199 & 99.5 \\
\hline & 6 & 1 & 0.5 \\
\hline & Total & 200 & 100 \\
\hline \multirow{3}{*}{ Program Studi } & Manajemen Keuangan - S1 & 81 & 40.5 \\
\hline & Akuntansi - S1 & 119 & 59.5 \\
\hline & Total & 200 & 100.0 \\
\hline
\end{tabular}

\section{Sumber: Data Primer Diolah, 2019}

\section{Pengetahuan Investasi Para Mahasiswa}

JAS-PT

JURNAL ANALISIS SISTEM PENDIDIKAN TING

ISSN $2580-5339$ eISSN $2620-5718$

Volume 3

Nomor 1

JULI 2019

Hal $31-52$

FORUM DOSEN INDONESIA

\section{Pengetahuan Pasar Modal}

Pengetahuan Pasar Modal merupakan pengetahuan tentang konsep dan manfaat keberadaan pasar modal. Persepsi responden terhadap pengetahuan pasar modal dibagi menjadi empat bagian yaitu :

a. Pasar Modal Sebagai Wadah Investasi Resmi. 91,3\% mahasiswa menjawab benar atas pernyataan pertama "pasar modal sebagai wadah investasi yang resmi yang 
mempertemukan pihak yang kelebihan dana dan pihak yang kekurangan dana". Sisanya, $0.5 \%$ responden menjawab salah dan $8 \%$ menjawab ragu-ragu. Hal ini menunjukkan bahwa mayoritas responden mengetahui bahwa pasar modal sebagai wadah investasi yang resmi.

b. Perusahaan, Masyarakat dan Kelebihan Dana. Pernyataan "pihak yang kelebihan dana adalah perusahaan dan pihak yang kekurangan dana adalah masyarakat", dibenarkan oleh $31 \%$ responden. $47 \%$ responden menyatakan pernyataan tersebut salah dan sisanya $32 \%$ responden menyatakan ragu-ragu. Hal ini menunjukkan bahwa $32 \%$ responden mengetahui bahwa yang kekurangan dana adalah perusahaan dan kelebihan dana adalah masyarakat.

c. Instrumen yang Dijual di Pasar Modal. 94\% responden menjawab benar atas pernyataan "pasar modal sebagai tempat menjual instrument keuangan seperti saham, obligasi, dan reksadana". Sisanya menjawab ragu (6\%). Hal ini menunjukkan bahwa mayoritas responden mengetahui bahwa pasar modal merupakan tempat memperperjualbelikan saham, obligasi dan reksadana.

d. Pasar Modal Sumber Pendanaan. Pernyataan "pasar modal sebagai salah satu wadah yang menyediakan sumber pendanaan bagi dunia usaha", dijawab benar oleh $100 \%$ responden. Hal ini menunjukkan bahwa seluruh responden mengetahui bahwa pasar modal sebagai salah satu sumber pendanaan bagi perusahaan.

Tabel 4. Persepsi Responden Tentang Pengetahuan Pasar Modal

\begin{tabular}{llcc}
\hline \multicolumn{1}{c}{ Pernyataan } & Persepsi Responden & Frekuensi & $\%$ \\
\hline Pasar modal adalah salah & Sangat Tidak Setuju & 0 & 0 \\
satu wadah investasi resmi & Tidak Setuju & 1 & 0,5 \\
yang mempertemukan pihak & Ragu-Ragu & 16 & 8,0 \\
yang kelebihan dana dengan & Setuju & 120 & 60,0 \\
pihak yang kekurangan dana & Sangat Setuju & 63 & 31,5 \\
& \multicolumn{1}{c}{ Total } & 200 & 100,0 \\
Pihak yang kelebihan dana & Sangat Tidak Setuju & 32 & 16,0 \\
adalah perusahaan dan pihak & Tidak Setuju & 42 & 21,0 \\
yang kekurangan dana & Ragu-ragu & 64 & 32,0 \\
adalah masyarakat & Setuju & 47 & 23,5 \\
& Sangat Setuju & 15 & 7,5 \\
Pasar modal adalah tempat & Total & 200 & 100,0 \\
menjual instrument keuangan & Sangat Tidak Setuju & 0 & 0 \\
seperti saham, obligasi dan & Ragu-Ragu & 0 & 0 \\
reksadana & Setuju & 12 & 6,0 \\
& Sangat Setuju & 102 & 51,0 \\
Pasar modal salah satu & Total & 86 & 43,0 \\
wadah yang menyediakan & Sangat Tidak Setuju & 200 & 100,0 \\
sumber pendanaan bagi & Tidak Setuju & 0 & 0 \\
dunia usaha/perusahaan & Ragu-ragu & 0 & 0 \\
& Setuju & 6 & 3,0 \\
& Sangat Setuju & 118 & 59,0 \\
& $\quad$ Total & 76 & 38,0 \\
& $\quad 200$ & 100,0 \\
\hline
\end{tabular}

Sumber: Data Primer Diolah, 2019

Penilaian atas respon atau persepsi Mahasiswa tentang Pengetahuan Investasi dapat dihitung menggunakan persamaan berikut ini:

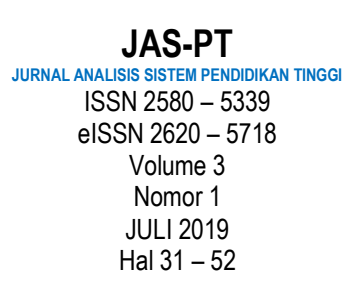

FORUM DOSEN INDONESIA 
a. Untuk mengetahui bobot nilai pertanyaan pengetahuan mahasiswa tentang pengetahuan investasi, yaitu :

$$
\frac{\text { Asumsi } 100 \%}{\text { Jumlah Pertanyaan }} \text { : Jumlah Responden }
$$

b. Untuk mencari persentase mahasiswa yang mengetahui tentang pasar modal dengan cara sebagai berikut :

\section{Total Variabel $x$ Bobot Pertanyaan}

Pengetahuan Mahasiswa tentang Pengetahuan Pasar Modal dapat dihitung sebagai berikut:

$\frac{100 \%}{4}: 200=12,5 \%$

Total Responden yang menjawab dengan jawaban Benar, Salah dan Ragu-ragu, dari jumlah total 200 responden dapat dilihat pada Gambar 1

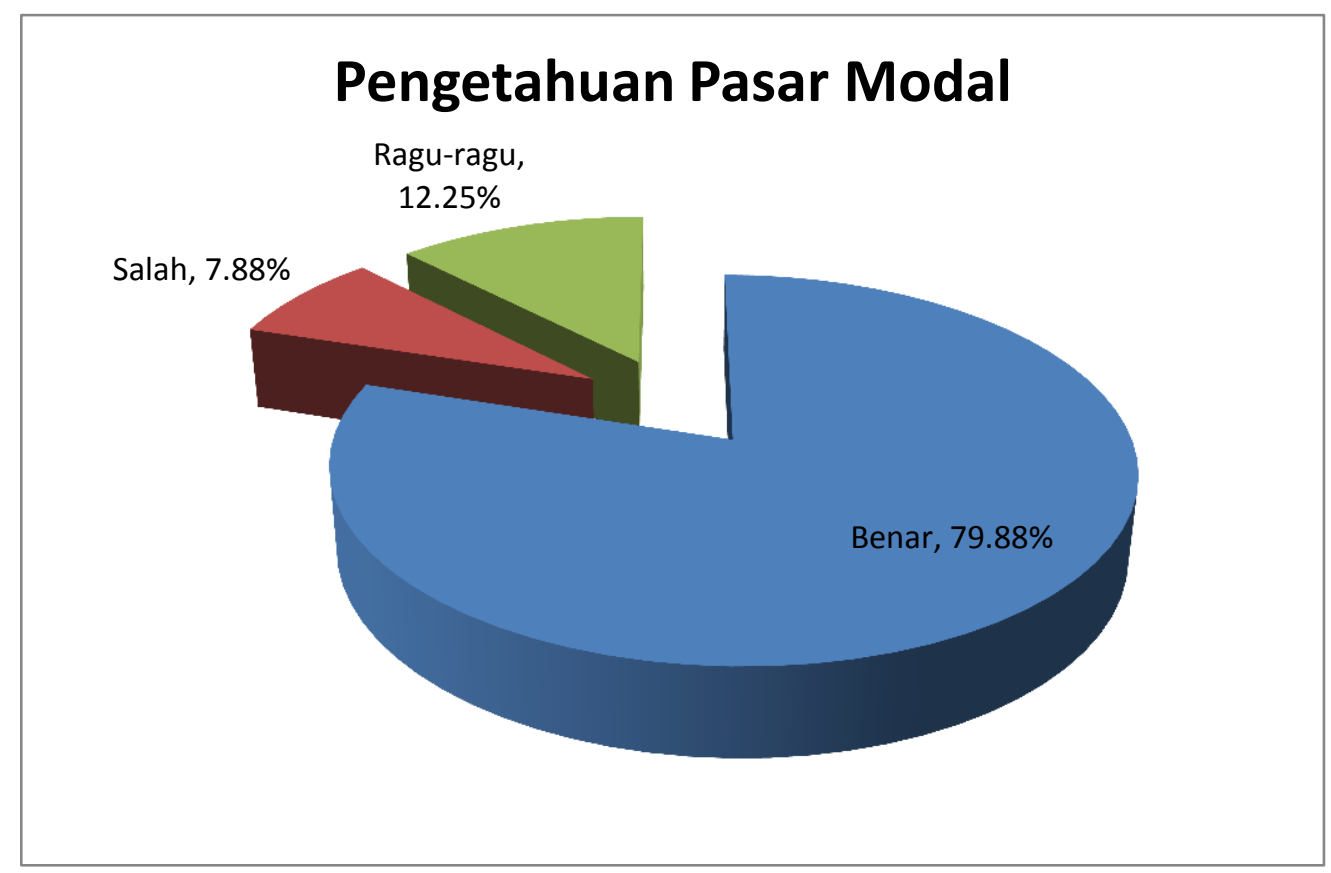

.Gambar 1 Grafik Jawaban Responden atas Pernyataan Pengetahuan Pasar Modal

\section{Pengetahuan Jenis Instrumen Investasi}

Persepsi responden terhadap pengetahuan jenis instrumen investasi dibagi menjadi empat bagian yaitu :

a. Saham Instrumen Keuangan Pasar Modal

Penyataan pertama "saham adalah salah satu instrument keuangan yang dijual di pasar modal yang diterbitkan oleh perusahaan", dinyatakan benar oleh 200 responden. Hal ini menunjukkan bahwa $100 \%$ responden mengetahui bahwa

JAS-PT

JURNAL ANALISIS SISTEM PENDIDIKAN TINGG

ISSN $2580-5339$

eISSN $2620-5718$

Volume 3

Nomor 1

JULI 2019

Hal $31-52$

FORUM DOSEN INDONESIA saham dijual di pasar modal dan diterbitkan oleh perusahaan.

b. Tempat Pembelian Saham

"Saham dapat dibeli di bank, koperasi dan pegadaian". Pernyataan tersebut dinyatakan keliru oleh $42,5 \%$ responden. Sisanya $27 \%$ responden menjawab ragu dan 30,5\% memberikan jawaban yang salah atas pernyataan tersebut. Hal ini menunjukkan bahwa $42,5 \%$ responden mengetahui bahwa saham dibeli di pasar modal, bukan dibeli di bank, koperasi atau pegadaian. 
c. Jangka Waktu Saham

Pernyataan ketiga yang menyebutkan "saham tidak memiliki jangka waktu atau jatuh tempo", dibenarkan oleh 116 orang responden. 10,5\% responden menjawab ragu dan sisanya 9,5\% menjawab salah. Hal ini menunjukkan bahwa $80 \%$ responden mengetahui bahwa saham tidak memiliki jangka waktu atau jatuh tempo.

d. Jangka Waktu Deposito dan Obligasi

Pada pernyataan keempat "deposito dan obligasi memiliki jangka waktu/jatuh tempo", responden yang menjawab dengan benar sebanyak $95 \%$, yang menjawab ragu sebanyak $4,5 \%$ dan yang menjawab salah $0,5 \%$. Hal ini menunjukkan bahwa 95\% responden mengetahui bahwa deposito dan obligasi memiliki jangka waktu atau jatuh tempo.

Tabel 5. Persepsi Responden Tentang Pengetahuan Jenis Instrumen Investasi

\begin{tabular}{llcc}
\hline \multicolumn{1}{c}{ Pernyataan } & \multicolumn{1}{c}{$\begin{array}{c}\text { Persepsi } \\
\text { Responden }\end{array}$} & Frekuensi & $\%$ \\
\hline Saham adalah salah satu & Sangat Tidak Setuju & 0 & 0 \\
instrument keuangan yang dijual & Tidak Setuju & 0 & 0 \\
di pasar modal yang diterbitkan & Ragu-Ragu & 0 & 0 \\
oleh perusahaan & Setuju & 102 & 51,0 \\
& Sangat Setuju & 98 & 49,0 \\
& \multicolumn{1}{c}{ Total } & 200 & 100,0 \\
Instrumen investasi saham dapat & Sangat Tidak Setuju & 33 & 16,5 \\
dibeli di bank, koperasi, dan & Tidak Setuju & 52 & 26,0 \\
pegadaian & Ragu-Ragu & 54 & 27,0 \\
& Setuju & 54 & 27,0 \\
& Sangat Setuju & 7 & 3,5 \\
Saham tidak memiliki jangka & Total & 200 & 100,0 \\
waktu/jatuh tempo & Sangat Tidak Setuju & 3 & 1,5 \\
& Tidak Setuju & 16 & 8,0 \\
& Ragu-Ragu & 21 & 10,5 \\
& Setuju & 92 & 46,0 \\
& Sangat Setuju & 68 & 34,0 \\
& $\quad$ Total & 200 & 100,0 \\
Deposito dan obligasi memiliki & Sangat Tidak Setuju & 0 & 0 \\
jangka waktu/jatuh tempo & Tidak Setuju & 1 & 0,5 \\
& Ragu-Ragu & 9 & 4,5 \\
& Setuju & 102 & 51,0 \\
& Sangat Setuju & 88 & 44,0 \\
& Total & 200 & 100,0 \\
\hline & & &
\end{tabular}

Sumber: Data Primer Diolah, 2019

Pengetahuan Mahasiswa tentang Pengetahuan Jenis Instrumen Investasi dapat dihitung sebagai berikut:

$\frac{100 \%}{4}: 200=12,5 \%$

Total Responden yang menjawab dengan jawaban Benar, Salah dan Ragu-ragu, dari jumlah total 200 responden dapat dilhat pada Gambar 2

JAS-PT

JURNAL ANALISIS SISTEM PENDIDIKAN TING

ISSN $2580-5339$

elSSN $2620-5718$

Volume 3

Nomor 1

JULI 2019

Hal $31-52$

FORUM DOSEN INDONESIA 


\section{Pengetahuan Jenis Instrumen Investasi}

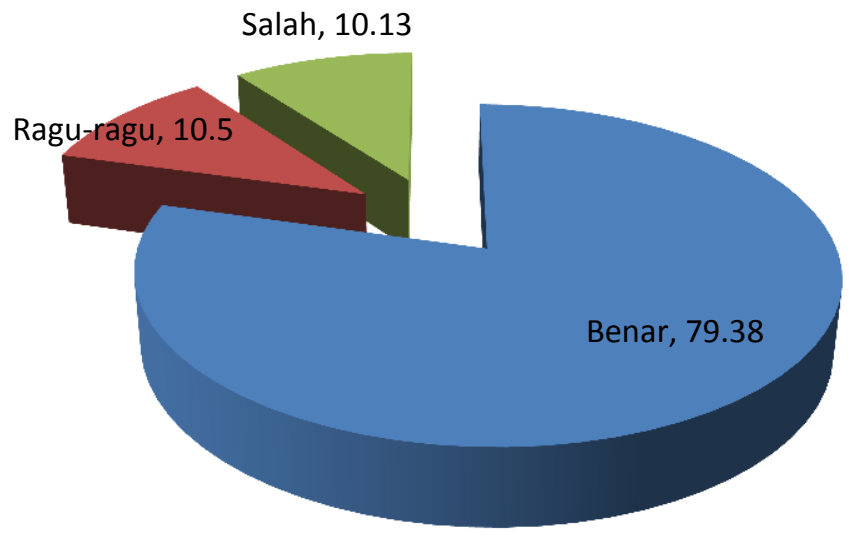

Gambar 2 Grafik Jawaban Responden atas Pernyataan Pengetahuan Jenis Instrumen Investasi

\section{Pengetahuan Tingkat Keuntungan}

Persepsi responden terhadap pengetahuan tingkat keuntungan dibagi menjadi enam bagian yaitu :

a. Dividen Keuntungan Investasi Saham.

194 orang responden menjawab benar atas pernyataan "investasi saham memberikan keuntungan berupa dividen". Sisanya 6 orang responden menjawab ragu-ragu atas pernyataan tersebut. Hal ini menunjukkan bahwa $97 \%$ responden mengetahui bahwa investasi saham memberikan keuntungan berupa dividen.

b. Pembagian Laba Perusahaan Kepada Investor

Responden yang menjawab benar sebanyak 124 orang atas pernyataan "perusahaan tidak akan pernah membagi labanya kepada investor dalam bentuk apapun". $28 \%$ responden menjawa ragu-ragu dan sisanya 10\% menjawab salah. Hal ini menunjukkan bahwa $62 \%$ responden mengetahui bahwa perusahaan akan membagikan labanya kepada investor.

c. Keuntungan Yang Diperoleh Dari Saham

Pada pernyataan ketiga "keuntungan dari saham juga dari capital gain yaitu selisih harga jual lebih tinggi dari harga beli", responden yang menjawab dengan benar sebanyak 188 orang dan yang menjawab salah 1 serta sisanya 11 orang menyatakan ragu-ragu. Hal ini menunjukkan bahwa $94 \%$ responden mengetahui bahwa keuntungan dari saham juga berasal dari capital gain.

d. Keuntungan Lain yang diperoleh dari Saham

Responden yang menjawab benar atas pernyataan "keuntungan dari saham juga dari bunga dan bonus investasi" adalah sebanyak 49 orang, dan yang menjawab

JAS-PT

JURNAL ANALISIS SISTEM PENDIDIKAN TINGG

ISSN $2580-5339$

eISSN $2620-5718$

Volume 3

Nomor 1

JULI 2019

Hal $31-52$

FORUM DOSEN INDONESIA salah 121 orang, sisanya 30 orang menjawa ragu. Hal ini menunjukkan bahwa $24.5 \%$ responden mengetahui bahwa keuntungan dari saham bukan berasal dari bunga dan bonus investasi.

e. Investasi Saham Lebih Menguntungkan.

Pada pernyataan kelima "berinvestasi saham menawarkan keuntungan lebih tinggi dibanding obligasi", responden yang menjawab dengan benar sebanyak 82 orang dan yang menjawab salah 5 orang sisanya menjawab ragu sebanyak 62 orang. 
Hal ini menunjukkan bahwa $66.5 \%$ responden mengetahui bahwa keuntungan dari saham lebih menguntungkan karena keuntungan diperoleh juga dari capital gain.

f. Investasi Deposito Lebih Menguntungkan

Pada pernyataan "berinvestasi deposito menawarkan keuntungan lebih tinggi dibanding saham", responden yang menjawab dengan benar sebanyak 35 orang dan yang menjawab salah sebanyak 59 orang, sisanya sebanyak 106 menjawab ragu-ragu. Hal ini menunjukkan bahwa $17,5 \%$ responden mengetahui bahwa berinvestasi deposito menawarkan keuntungan yang lebih rendah dibanding saham.

Tabel 6. Persepsi Responden Tentang Pengetahuan Tingkat Keuntungan

\begin{tabular}{|c|c|c|c|}
\hline Pernyataan & $\begin{array}{l}\text { Persepsi } \\
\text { Responden }\end{array}$ & Frekuensi & $\%$ \\
\hline Investasi saham memberikan & Sangat Tidak Setuju & 0 & 0 \\
\hline \multirow[t]{5}{*}{ keuntungan berupa dividen } & Tidak Setuju & 0 & 0 \\
\hline & Ragu-Ragu & 6 & 3,0 \\
\hline & Setuju & 84 & 42,0 \\
\hline & Sangat Setuju & 110 & 55,0 \\
\hline & Total & 200 & 100,0 \\
\hline \multirow{6}{*}{$\begin{array}{l}\text { Perusahaaan tidak akan pernah } \\
\text { membagi labanya kepada investor } \\
\text { dalam bentuk apapun }\end{array}$} & Sangat Tidak Setuju & 52 & 26,0 \\
\hline & Tidak Setuju & 72 & 36,0 \\
\hline & Ragu-Ragu & 56 & 28,0 \\
\hline & Setuju & 17 & 8,5 \\
\hline & Sangat Setuju & 3 & 1,5 \\
\hline & Total & 200 & 100,0 \\
\hline \multirow{6}{*}{$\begin{array}{l}\text { Keuntungan dari saham juga dari } \\
\text { capital gain-nya itu selisih harga } \\
\text { jual lebih tinggi dari harga beli }\end{array}$} & Sangat Tidak Setuju & 0 & 0 \\
\hline & Tidak Setuju & 1 &, 5 \\
\hline & Ragu-Ragu & 11 & 5,5 \\
\hline & Setuju & 122 & 61,0 \\
\hline & Sangat Setuju & 66 & 33,0 \\
\hline & Total & 200 & 100,0 \\
\hline \multirow{6}{*}{$\begin{array}{l}\text { Keuntungan dari saham juga dari } \\
\text { bunga dan bonus investasi }\end{array}$} & Sangat Tidak Setuju & 10 & 5,0 \\
\hline & Tidak Setuju & 39 & 19,5 \\
\hline & Ragu-Ragu & 30 & 15,0 \\
\hline & Setuju & 116 & 58,0 \\
\hline & Sangat Setuju & 5 & 2,5 \\
\hline & Total & 200 & 100,0 \\
\hline \multirow{6}{*}{$\begin{array}{l}\text { Berinvestasi saham menawarkan } \\
\text { keuntungan lebih tinggi dibanding } \\
\text { obligasi }\end{array}$} & Sangat Tidak Setuju & 0 & 0 \\
\hline & Tidak Setuju & 5 & 2,5 \\
\hline & Ragu-Ragu & 62 & 31,0 \\
\hline & Setuju & 96 & 48,0 \\
\hline & Sangat Setuju & 37 & 18,5 \\
\hline & Total & 200 & 100,0 \\
\hline \multirow{6}{*}{$\begin{array}{l}\text { Berinvestasi deposito menawarkan } \\
\text { keuntungan lebih tinggi dibanding } \\
\text { saham }\end{array}$} & Sangat Tidak Setuju & 10 & 5,0 \\
\hline & Tidak Setuju & 25 & 12,5 \\
\hline & Ragu-Ragu & 106 & 53,0 \\
\hline & Setuju & 51 & 25,5 \\
\hline & Sangat Setuju & 8 & 4,0 \\
\hline & Total & 200 & 100,0 \\
\hline
\end{tabular}

JAS-PT

JURNAL ANALISIS SISTEM PENDIDIKAN TINGG ISSN $2580-5339$ eISSN $2620-5718$

Volume 3

Nomor 1

JULI 2019

Hal $31-52$ 
Pengetahuan Mahasiswa tentang Pengetahuan Tingkat Keuntungan Investasi dapat dihitung sebagai berikut:

$\frac{100 \%}{6}: 200=8,33 \%$

Total Responden yang menjawab dengan jawaban Benar, Salah dan Ragu-ragu, dari jumlah total 200 responden, sebagaimana tampilan pada Gambar 3.

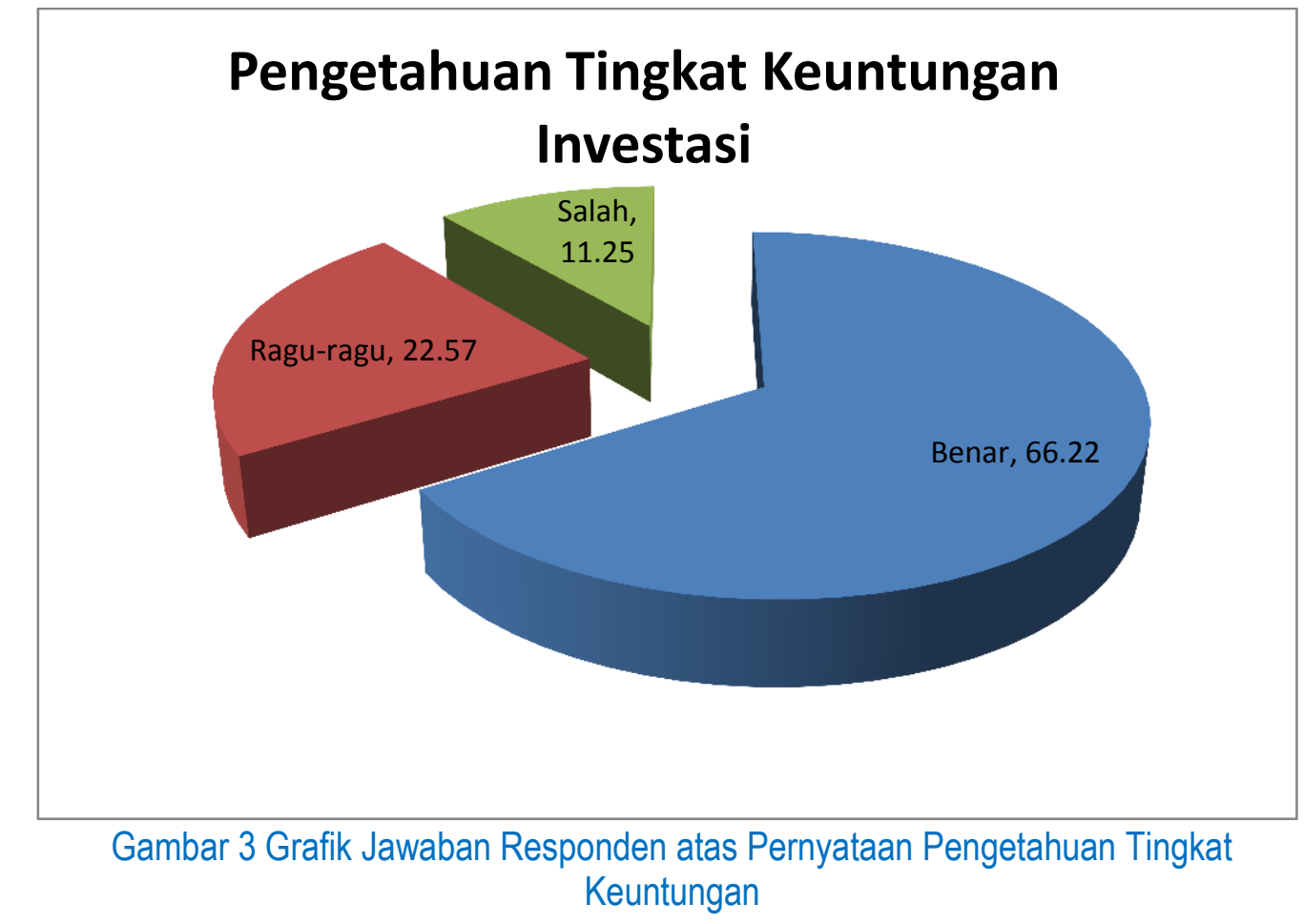

\section{Pengetahuan Tingkat Risiko}

Persepsi responden terhadap pengetahuan tingkat risiko dibagi menjadi sebelas bagian yaitu :

a. Prinsip Investasi Saham

Pada pernyataan pertama "Prinsip investasi saham yaitu risiko tinggi keuntungan tinggi, dan risiko rendah keuntungan rendah", responden yang menjawab dengan benar sebanyak 193 orang dan yang menjawab ragu 7 orang. Hal ini menunjukkan bahwa $96,5 \%$ responden mengetahui bahwa prinsip investasi saham yaitu risiko tinggi keuntungan tinggi, resiko rendah keuntungan juga rendah.

b. Risiko Investasi Saham

Pada pernyataan kedua "risiko investasi saham berbanding terbalik dengan keuntungan", responden yang menjawab dengan benar sebanyak 87 orang dan yang menjawab salah 48 orang, sisanya 65 orang menjawa ragu. Hal ini menunjukkan bahwa $43,5 \%$ responden mengetahui bahwa risiko investasi saham

JAS-PT

JURNAL ANALISIS SISTEM PENDIDIKAN TINGG

ISSN $2580-5339$ eISSN $2620-5718$

Volume 3

Nomor 1

JULI 2019

Hal $31-52$

FORUM DOSEN INDONESIA berbanding lurus dengan keuntungan.

c. Tidak Memperoleh Dividen Adalah Risiko Investasi Saham

Pada pernyataan ketiga "salah satu risiko membeli saham yaitu tidak mendapatkan dividen", responden yang menjawab dengan benar sebanyak 78 orang dan yang menjawab salah 48 orang, sisanya menjawab ragu sebanyak 74 orang. Hal ini menunjukkan bahwa $39 \%$ responden mengetahui bahwa salah satu risiko investasi saham tidak mendapatkan dividen. 
d. Risiko Kebangkrutan Pada Perusahaan Yang Menjual Saham

Pada pernyataan keempat "perusahaan yang menjual sahamnya ke masyarakat dapat mengalami kebangkrutan", responden yang menjawab dengan benar sebanyak 39 orang dan yang menjawab salah 59 orang, sisanya menjawab ragu sebanyak 102 orang responden. Hal ini menunjukkan bahwa 19,5\% responden mengetahui bahwa perusahaan yang menjual sahamnya ke masyarakat dapat mengalami kebangkrutan.

e. Capital Loss Merupakan Kerugian Membeli Saham

Pada pernyataan kelima "kerugian membeli saham juga berasal dari capital loss yaitu harga jual lebih rendah dari harga beli", responden yang menjawab dengan benar sebanyak 181 orang dan yang menjawab salah 7 orang, sisanya menjawab ragu sebanyak 12 orang. Hal ini menunjukkan bahwa 90,5\% responden mengetahui bahwa kerugian membeli saham juga berasal dari capital loss yaitu harga jual lebih rendah dari harga beli.

f. Pemegang Saham Pemilik Hak Terakhir Kekayaan Perusahaan

Pada pernyataan keenam "pemegang saham memiliki hak terakhir dalam pembagian kekayaan perusahaan jika perusahaan mengalami kebangkrutan", responden yang menjawab dengan benar sebanyak 129 orang dan yang menjawab salah 18 orang, sisanya menjawab ragu sebanyak 53 orang. Hal ini menunjukkan bahwa $64,5 \%$ responden mengetahui bahwa pemegang saham memiliki hak terakhir dalam pembagian kekayaan perusahaan jika perusahaan mengalami kebangkrutan

g. Investasi Saham Berisiko Lebih Tinggi Dibanding Obligasi

Pada pernyataan ketujuh "investasi saham memiliki risiko lebih tinggi dibanding obligasi" responden yang menjawab dengan benar sebanyak 157 orang dan yang menjawab salah 8 orang, sisanya menjawab ragu sebanyak 35 orang. Hal ini menunjukkan bahwa $78,5 \%$ responden mengetahui bahwa investasi saham memiliki risiko lebih tinggi dibanding obligasi.

h. Risiko Investasi Saham dan Obligasi

Pada pernyataan ketujuh "investasi saham memiliki risiko lebih rendah dibanding deposito", responden yang menjawab dengan benar sebanyak 57 orang dan yang menjawab salah 43 orang, sisanya menjawab ragu seanyak 100 orang. Hal ini menunjukkan bahwa 28,5\% responden mengetahui bahwa investasi saham memiliki risiko lebih tinggi dibanding deposito.

i. Manfaat Mengukur Tingkat Risiko

Pada pernyataan "Mengukur tingkat risiko membantu investor dalam meminimalisir kerugian", responden yang menjawab dengan benar sebanyak 197 orang dan yang menjawab ragu-ragu sebanyak 13 orang serta tidak ada yang menjawab salah. Hal ini menunjukkan bahwa 93,5\% responden mengetahui bahwa upaya mengukur tingkat risiko dapat memantu investor meminimalisir kerugian.

j. Pilihan Investasi Risiko Rendah

Pada pernyataan "Lebih baik memilih investasi dengan tingkat risiko rendah", responden yang menjawab dengan benar sebanyak 12 orang dan yang menjawab ragu-ragu sebanyak 80 orang, sisanya sebanyak 108 orang menjawab salah. Hal ini menunjukkan bahwa $6 \%$ responden mengetahui bahwa memilih investasi dengan tingkat risiko rendah bukan pilihan terbaik bagi investor. Pilihan tersebut akan menjadi terbaik bagi investor dengan tipe risk averse.

k. Pilihan Investasi Risiko Tinggi

Pada pernyataan "Investasi dengan tingkat risiko tinggi namun return-nya tinggi merupakan tantangan menarik", responden yang menjawab dengan benar

JAS-PT

JURNAL ANALISIS SISTEM PENDIDIKAN TINGGI

ISSN 2580 - 5339

eISSN $2620-5718$

Volume 3

Nomor 1

JULI 2019

Hal $31-52$

FORUM DOSEN INDONESIA 
sebanyak 184 orang dan yang menjawab ragu-ragu sebanyak 16 orang. Hal ini menunjukkan bahwa $92 \%$ responden mengetahui bahwa investasi dengan tingkat risiko tinggi dan retunr yang tinggi merupakan tantangan menarik bagi investor dengan tipe risk taker.

Tabel 7. Persepsi Responden Tentang Pengetahuan Tingkat Risiko

\begin{tabular}{|c|c|c|c|}
\hline Pernyataan & Persepsi Responden & Frekuensi & $\%$ \\
\hline \multirow{6}{*}{$\begin{array}{l}\text { Prinsip Investasi Saham } \\
\text { yaitu risiko tinggi } \\
\text { keuntungan tinggi, risiko } \\
\text { rendah keuntungan rendah }\end{array}$} & Sangat Tidak Setuju & 0 & 0 \\
\hline & Tidak Setuju & 0 & 0 \\
\hline & Ragu-Ragu & 7 & 3,5 \\
\hline & Setuju & 91 & 45,5 \\
\hline & Sangat Setuju & 102 & 51,0 \\
\hline & Total & 200 & 100,0 \\
\hline \multirow{6}{*}{$\begin{array}{l}\text { Risiko investasi saham } \\
\text { berbanding terbalik dengan } \\
\text { keuntungan }\end{array}$} & Sangat Tidak Setuju & 35 & 17,5 \\
\hline & Tidak Setuju & 52 & 26,0 \\
\hline & Ragu-Ragu & 65 & 32,5 \\
\hline & Setuju & 43 & 21,5 \\
\hline & Sangat Setuju & 5 & 2,5 \\
\hline & Total & 200 & 100,0 \\
\hline \multirow{6}{*}{$\begin{array}{l}\text { Salah satu risiko membeli } \\
\text { saham adalah tidak } \\
\text { mendapatkan dividen }\end{array}$} & Sangat Tidak Setuju & 23 & 11,5 \\
\hline & Tidak Setuju & 25 & 12,5 \\
\hline & Ragu-Ragu & 74 & 37,0 \\
\hline & Setuju & 59 & 29,5 \\
\hline & Sangat Setuju & 19 & 9,5 \\
\hline & Total & 200 & 100,0 \\
\hline \multirow{6}{*}{$\begin{array}{l}\text { Perusahaan yang menjual } \\
\text { sahamnya ke masyarakat } \\
\text { (go public) dapat mengalami } \\
\text { kebangkrutan }\end{array}$} & Sangat Tidak Setuju & 26 & 13,0 \\
\hline & Tidak Setuju & 33 & 16,5 \\
\hline & Ragu-Ragu & 102 & 51,0 \\
\hline & Setuju & 34 & 17,0 \\
\hline & Sangat Setuju & 5 & 2,5 \\
\hline & Total & 200 & 100,0 \\
\hline \multirow{6}{*}{$\begin{array}{l}\text { Kerugian membeli saham } \\
\text { juga berasal dari capital loss } \\
\text { yaitu harga jual lebih rendah } \\
\text { dari harga beli }\end{array}$} & Sangat Tidak Setuju & 3 & 1,5 \\
\hline & Tidak Setuju & 4 & 2,0 \\
\hline & Ragu-Ragu & 12 & 6,0 \\
\hline & Setuju & 131 & 65,5 \\
\hline & Sangat Setuju & 50 & 25,0 \\
\hline & Total & 200 & 100,0 \\
\hline \multirow{6}{*}{$\begin{array}{l}\text { Pemegang saham memiliki } \\
\text { hak terakhir dalam } \\
\text { pembagian kekayaan } \\
\text { perusahaan jika perusahaan } \\
\text { bangkrut }\end{array}$} & Sangat Tidak Setuju & 2 & 1,0 \\
\hline & Tidak Setuju & 16 & 8,0 \\
\hline & Ragu-Ragu & 53 & 26,5 \\
\hline & Setuju & 106 & 53,0 \\
\hline & Sangat Setuju & 23 & 11,5 \\
\hline & Total & 200 & 100,0 \\
\hline \multirow{6}{*}{$\begin{array}{l}\text { Investasi saham memiliki } \\
\text { risiko lebih tinggi dibanding } \\
\text { obligasi }\end{array}$} & Sangat Tidak Setuju & 1 &, 5 \\
\hline & Tidak Setuju & 7 & 3,5 \\
\hline & Ragu-Ragu & 35 & 17,5 \\
\hline & Setuju & 107 & 53,5 \\
\hline & Sangat Setuju & 50 & 25,0 \\
\hline & Total & 200 & 100,0 \\
\hline
\end{tabular}


Tabel 7. (Lanjutan)

\begin{tabular}{llcc}
\hline \multicolumn{1}{c}{ Pernyataan } & Persepsi Responden & Frekuensi & $\%$ \\
\hline Investasi saham memiliki & Sangat Tidak Setuju & 31 & 15,5 \\
risiko yang lebih rendah & Tidak Setuju & 26 & 13,0 \\
dibanding deposito & Ragu-Ragu & 100 & 50,0 \\
& Setuju & 37 & 18,5 \\
& Sangat Setuju & 6 & 3,0 \\
Mengukur tingkat risiko & \multicolumn{1}{c}{ Total } & 200 & 100,0 \\
membantu investor dalam & Sangat Tidak Setuju & 0 & 0 \\
meminimalisir kerugian & Tidak Setuju & 0 & 0 \\
& Ragu-Ragu & 13 & 6,5 \\
& Setuju & 122 & 61,0 \\
& Sangat Setuju & 65 & 32,5 \\
Lebih baik memilih investasi & Sangat Tidak Setuju & 200 & 100,0 \\
dengan tingkat risiko rendah & Tidak Setuju & 1 &, 5 \\
& Ragu-Ragu & 11 & 5,5 \\
& Setuju & 80 & 40,0 \\
& Sangat Setuju & 88 & 44,0 \\
& & 20 & 10,0 \\
Investasi dengan tingkat & Total & 200 & 100,0 \\
risiko tinggi namun return- & Tidak Setuju & 0 & 0 \\
nya tinggi merupakan & Ragu-Ragu & 0 & 0 \\
tantangan menarik & Setuju & 16 & 8,0 \\
& Sangat Setuju & 106 & 53,0 \\
& $\quad$ Total & 78 & 39,0 \\
& $\quad 200$ & 100,0 \\
\hline
\end{tabular}

Sumber: Data Primer Diolah, 2019

\section{Pengetahuan Tingkat Risiko Investasi}

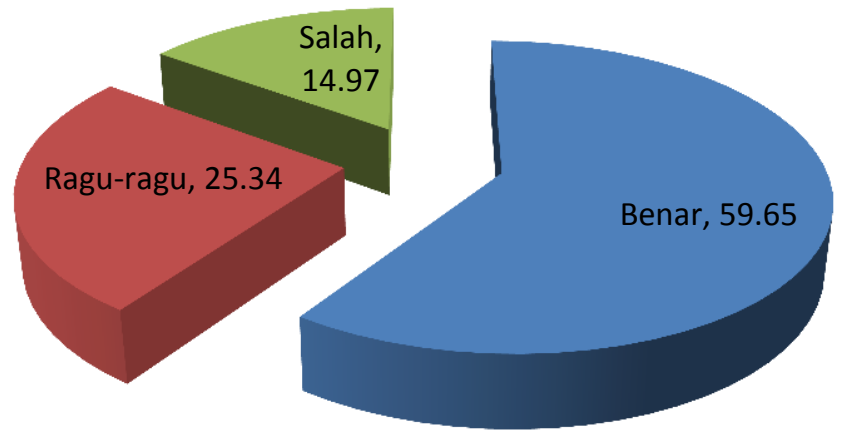

Gambar 4 Grafik Jawaban Responden atas Pernyataan Pengetahuan Tingkat Risiko Investasi

Pengetahuan Mahasiswa tentang Pengetahuan Tingkat Risiko Investasi dapat dihitung sebagai berikut:

$\frac{100 \%}{11}: 200=4,55 \%$

JAS-PT

JURNAL ANALISIS SISTEM PENDIDIKAN TINGG ISSN $2580-5339$ eISSN $2620-5718$

Volume 3

Nomor 1

JULI 2019

Hal $31-52$

FORUM DOSEN INDONESIA 
Total Responden yang menjawab dengan jawaban Benar, Salah dan Ragu-ragu, dari jumlah total 200 responden, sebagaimana Gambar 4.

\section{Pengetahuan Dasar Penilaian Saham}

Tabel 8. Persepsi Responden Tentang Pengetahuan Dasar Penilaian Saham

\begin{tabular}{|c|c|c|c|}
\hline Pernyataan & Persepsi Responden & Frekuensi & $\%$ \\
\hline Sebagai calon investor, & Sangat Tidak Setuju & 0 & 0 \\
\hline pengetahuan dasar tentang & Tidak Setuju & 0 & 0 \\
\hline \multirow{4}{*}{ investasi sangat penting } & Ragu-Ragu & 0 & 0 \\
\hline & Setuju & 37 & 18,5 \\
\hline & Sangat Setuju & 163 & 81,5 \\
\hline & Total & 200 & 100,0 \\
\hline \multirow{6}{*}{$\begin{array}{l}\text { Sekolah pasar modal } \\
\text { membantu investor untuk } \\
\text { menambah pengetahuan } \\
\text { investasi }\end{array}$} & Sangat Tidak Setuju & 0 & 0 \\
\hline & Tidak Setuju & 0 & 0 \\
\hline & Ragu-Ragu & 3 & 1,5 \\
\hline & Setuju & 77 & 38,5 \\
\hline & Sangat Setuju & 120 & 60,0 \\
\hline & Total & 200 & 100,0 \\
\hline \multirow{6}{*}{$\begin{array}{l}\text { Mata kuliah teori portofolio } \\
\text { membantu saya dalam } \\
\text { memahami jenis investasi }\end{array}$} & Sangat Tidak Setuju & 0 & 0 \\
\hline & Tidak Setuju & 0 & 0 \\
\hline & Ragu-Ragu & 6 & 3,0 \\
\hline & Setuju & 124 & 62,0 \\
\hline & Sangat Setuju & 70 & 35,0 \\
\hline & Total & 200 & 100,0 \\
\hline \multirow{6}{*}{$\begin{array}{l}\text { Pemahaman tentang } \\
\text { pengetahuan dasar } \\
\text { investasi wajib dikuasai } \\
\text { sebelum melakukan } \\
\text { investasi }\end{array}$} & Sangat Tidak Setuju & 0 & 0 \\
\hline & Tidak Setuju & 0 & 0 \\
\hline & Ragu-Ragu & 2 & 1,0 \\
\hline & Setuju & 102 & 51,0 \\
\hline & Sangat Setuju & 96 & 48,0 \\
\hline & Total & 200 & 100,0 \\
\hline
\end{tabular}

\section{Sumber: Data Primer Diolah, 2019}

Persepsi responden terhadap pengetahuan dasar penilaian saham dibagi menjadi empat bagian yaitu :

a. Pentingnya Pengetahuan Dasar Investasi

Pada pernyataan "Sebagai calon investor, pengetahuan dasar tentang investasi sangat penting", responden yang menjawab dengan benar sebanyak 200 orang. Hal ini menunjukkan bahwa 100\% responden mengetahui bahwa pengetahaun dasar investasi sangat penting sebagai modal awal bagi calon investor.

b. Peran Sekolah Pasar Modal

Pada pernyataan "Sekolah pasar modal membantu investor untuk menambah pengetahuan investasi", responden yang menjawab dengan benar sebanyak 200 orang. Hal ini menunjukkan bahwa 100\% responden mengetahui bahwa

JAS-PT

JURNAL ANALISIS SISTEM PENDIDIKAN TINGG ISSN $2580-5339$ elSSN $2620-5718$

Volume 3

Nomor 1

JULI 2019

Hal $31-52$

FORUM DOSEN INDONESIA pengetahuan investasi dapat ditingkatkan melalui sekolah pasar modal.

c. Peran Mata Kuliah Teori Portofolio

Pada pernyataan "Mata kuliah teori portofolio membantu saya dalam memahami jenis investasi", responden yang menjawab dengan benar sebanyak 194 orang dan yang menjawab ragu sebanyak 6 orang. Hal ini menunjukkan bahwa $97 \%$ responden mengetahui bahwa pengetahuan investasi dapat ditingkatkan melalui mata kuliah Teori Portofolio. 


\section{d. Peran Mata Kuliah Teori Portofolio}

Pada pernyataan "Pemahaman tentang pengetahuan dasar investasi wajib dikuasai sebelum melakukan investasi", responden yang menjawab dengan benar sebanyak 198 orang dan yang menjawab ragu sebanyak 2 orang. Hal ini menunjukkan bahwa 99\% responden mengetahui bahwa pengetahuan investasi wajib dikuasai sebelum melakukan investasi.

Pengetahuan Mahasiswa tentang Pengetahuan Dasar Penilaian Saham dapat dihitung sebagai berikut:

$\frac{100 \%}{4}: 200=12,5 \%$

Total Responden yang menjawab dengan jawaban Benar, Salah dan Ragu-ragu, dari jumlah total 200 responden, sebagaimana terlihat pada Gambar 5/

\section{Pengetahuan Dasar Penilaian Saham}

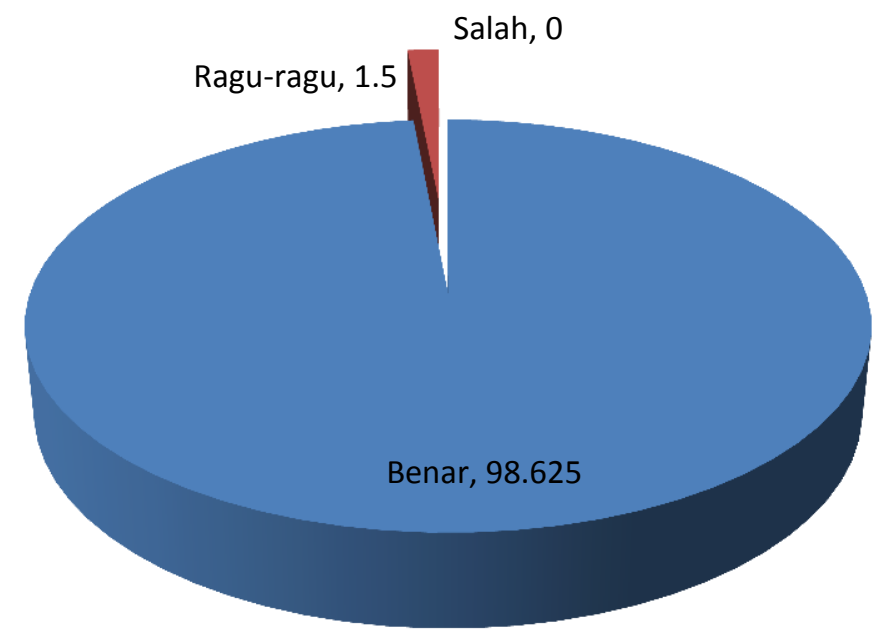

Gambar 5 Grafik Jawaban Responden atas Pernyataan Pengetahuan Dasar Penilaian Saham

Secara empiris, pengetahuan tentang investasi mempengaruhi minat, keinginan, aktivitas atau kegiatan berinvestasi para calon investor dan investor dari berbagai latar belakang pendidikan dan pekerjaan. Rizky Chaerul Pajar (2017) telah membuktikan adanya pengaruh pengetahuan investasi terhadap minat berinvestasi di pasar modal pada mahasiswa FE UNY. Husnul Khotimah (2016) telah menunjukkan bahwa pengetahuan baik secara parsial maupun secara bersama-sama (dengan variabel sosialisasi) berpengaruh signifikan terhadap minat investor. Rima Wijayanti (2015) menyatakan bahwa Pengetahuan berpengaruh siginifikan terhadap minat mahasiswa berinvestasi Dinar. Jika minat dan kegiatan berinvestasi meningkat, akan berimplikasi positif pada pengembangan Galeri Investasi di Perguruan Tinggi yang selama ini sedang dikembangkan di berbagai kampus.

Selanjutnya yang perlu diuraikan adalah pengetahuan investasi yang perlu dimiliki. Beberapa teori yang penulis berhasil identifikasi, menunjukkan bahwa pengetahuan dimaksud adalah Pengetahuan Pasar Modal, Pengetahuan Jenis Instrumen Investasi,

JAS-PT

JURNAL ANALISIS SISTEM PENDIDIKAN TINGGI ISSN $2580-5339$ elSSN $2620-5718$ Volume 3 Nomor 1 JULI 2019 Hal $31-52$

FORUM DOSEN INDONESIA 
Pengetahuan Tingkat Keuntungan, Pengetahuan Tingkat Risiko dan Pengetahuan Dasar Penilaian Saham. Hasil penelitian pada mahasiswa S1 Manajemen Keuangan dan S1 Akuntansi STIE Kesatuan menunjukkan masih ragamnya tingkat pemahaman dan pengetahuan para mahasiswa terkait pengetahuan investasi tersebut. Sebagian pengetahuan telah diketahui dan dipahami dengan baik oleh mahasiswa, namun terdapat sebagian darinya masih dipahami secara dangkal.

Pengetahuan Pasar Modal dipahami dengan baik oleh $79,88 \%$ responden. Hal yang belum dipahami dengan baik dalam aspek Pengetahuan Pasar Modal ini adalah tentang Pihak yang memiliki Kelebihan Dana antara Masyarakat atau Perusahaan. Merujuk pada teori dan konsep, adanya pasar modal adalah untuk menjembatani kekurangan dana yang sering dialami perusahaan, dengan memberi kesempatan kepada masyarakat untuk berinvestasi di instrumen dan perusahaan yang diminatinya. Pengelola Galeri Investasi dan Perguruan Tinggi masih perlu memberikan pemahaman yang mendalam terkait konsep sederhana ini melalui simulasi atau proses penjelasan dengan ilustrasi yang mudah dipahami.

Pengetahuan Jenis Instrumen Investasi dipahami dengan baik oleh responden (79,375\%). Hal yang belum dipahami dengan baik dalam aspek Pengetahuan Jenis Instrumen Investasi ini adalah terkait Tempat Memperoleh Saham. Masih ada responden yang menyatakan bahwa investasi saham dapat dibeli di bank, koperasi dan pegadaian. Secara teoritis dan prakteknya, investasi saham hanya bisa dilakukan di Pasar Modal, salah satunya melalui Galeri Investasi Perguruan Tinggi. Pemberian pemahaman tentang peran dan fungsi Galeri Investasi sebagai wadah untuk berinvestasi saham harus terus dilakukan dengan menjelaskan fungsinya atau pun melakukan kunjungan ke Galeri Investasi di Kampusnya masing-masing.

Pengetahuan Tingkat Keuntungan dipahami para mahasiswa pada level baik $(66,22 \%)$. Masih banyak mahasiswa yang menjawab Ragu-ragu (22,57\%) tentang Pengetahuan Tingkat Keuntungan Investasi ini. Hal yang belum dipahami dengan baik adalah masih bercampurnya konsep keuntungan yang diperoleh instrumen investasi di pasar modal dan perbankan. Hampir separuh responden menyatakan bahwa investasi saham akan juga memperoleh keuntungan berupa bunga dan bonus investasi. Mahasiswa masih harus dipahamkan lebih jauh tentang konsep bunga, gain dan bonus investasi. Mahasiswa harus dipahamkan tentang produk pasar modal dan produk perbankan. Penjelasan oleh Customer Service Galeri Investasi Perguruan Tinggi dan Dosen Pengajar Mata Kuliah Pasar Modal dan Teori Portofolio akan membantu mahasiswa memahami secara mendalam akan hal tersebut.

Pengetahuan Tingkat Risiko Investasi baru dipahami para mahasiswa pada level cukup baik. 59,65\% responden menjawab benar atas 11 (sebelas) pernyataan yang diajukan. Hal yang belum dipahami dengan baik adalah terkait bentuk risiko investasi saham berupa tidak mendapatkan dividen dan kemungkinan bangkrut bagi perusahaan yang telah go public. Pernyataan terkait dua hal tersebut masih dijawab ragu-ragu dan keliru oleh lebih dari separuh responden. Mahasiswa masih harus dipahamkan bahwa tidak mendapatkan dividen merupakan salah satu risiko yang akan dihadapi investor. Hal

JAS-PT

JURNAL ANALISIS SISTEM PENDIDIKAN TINGGI ISSN $2580-5339$ eISSN $2620-5718$ Volume 3

Nomor 1

JULI 2019

Hal $31-52$

FORUM DOSEN INDONESIA tersebut sangat mungkin terjadi. Bahkan perusahaan bisa saja mengambil keputusan dividen tidak dibagikan. Mahasiswa pun perlu dipahamkan bahwa Perusahaan yang telah go public masih berpotensi mengalami kebangkrutan. Banyak faktor penyebab kebangkrutan, sekalipun perusahaan sarat dengan pendanaan. Bukti empiris atau fakta terdahulu yang memberikan gambaran tentang perusahaan yang tidak membagi dividen dan perusahaan yang mengalami kebangkrutan setelah go public perlu disampaikan kepada mahasiswa calon investor. 
Pengetahuan Dasar Penilaian Saham sudah dipahami dengan sangat baik oleh para mahasiswa (98,63 menjawab dengan benar). Dari empat pernyataan yang disampaikan, masih ada responden yang menjawab ragu-ragu terkait materi kuliah Teori Portofolio yang akan memberi pemahaman tentang jenis investasi di Pasar Modal. Kemungkinan besar, mahasiswa tersebut telah memperoleh pemahaman jenis investasi di materi kuliah lainnya.

\section{PENUTUP}

\section{Simpulan}

Beberapa simpulan penelitian ini adalah sebagai berikut :

1. Pengetahuan Pasar Modal terdiri dari (a) Pasar Modal Sebagai Wadah Investasi Resmi, (b) Perusahaan, Masyarakat dan Kelebihan Dana, (c) Instrumen yang Dijual di Pasar Modal, (d) Pasar Modal Sumber Pendanaan. Hal yang belum dipahami dengan baik dalam aspek Pengetahuan Pasar Modal ini adalah tentang Pihak yang memiliki Kelebihan Dana antara Masyarakat atau Perusahaan.

2. Pengetahuan Jenis Instrumen Investasi terdiri dari (a) Saham Instrumen Keuangan Pasar Modal, (b) Tempat Pembelian Saham, (c) Jangka Waktu Saham, (d) Jangka Waktu Deposito dan Obligasi. Hal yang belum dipahami dengan baik dalam aspek Pengetahuan Jenis Instrumen Investasi ini adalah terkait Tempat Memperoleh Saham

3. Pengetahuan Tingkat Keuntungan Investasi terdiri dari (a) Dividen Keuntungan Investasi Saham (b) Pembagian Laba Perusahaan Kepada Investor, (c) Keuntungan Yang Diperoleh Dari Saham, (d) Keuntungan Lain yang diperoleh dari Saham, (e) Investasi Saham Lebih Menguntungkan, (f) Investasi Deposito Lebih Menguntungkan. Hal yang belum dipahami dengan baik adalah masih bercampurnya konsep keuntungan yang diperoleh instrumen investasi di pasar modal dan perbankan.

4. Pengetahuan Tingkat Risiko Investasi terdiri dari (a) Prinsip Investasi Saham, (b) Risiko Investasi Saham, (c) Tidak Memperoleh Dividen Adalah Risiko Investasi Saham, (d) Risiko Kebangkrutan Pada Perusahaan Yang Menjual Saham, (e) Capital Loss Merupakan Kerugian Membeli Saham, (f) Pemegang Saham Pemilik Hak Terakhir Kekayaan Perusahaan, (g) Investasi Saham Berisiko Lebih Tinggi Dibanding Obligasi, (h) Risiko Investasi Saham dan Obligasi, (i) Manfaat Mengukur Tingkat Risiko, (j) Pilihan Investasi Risiko Rendah, (k) Pilihan Investasi Risiko Tinggi. Hal yang belum dipahami dengan baik adalah terkait bentuk risiko investasi saham berupa tidak mendapatkan dividen dan kemungkinan bangkrut bagi perusahaan yang telah go public.

5. Pengetahuan dasar penilaian saham terdiri dari (a) Pentingnya Pengetahuan Dasar Investasi, (b) Peran Sekolah Pasar Modal, (c) Peran Mata Kuliah Teori Portofolio , (d) Peran Mata Kuliah Teori Portofolio. Semua mahasiswa sudah memahami dengan baik tentang pengetahuan dasar penilaian saham.

\section{Saran}

Berdasarkan hasil penelitian dapat disampaikan saran sebagai berikut :

1. Pengembangan Galeri Investasi Perguruan Tinggi harus disertai pula dengan pengembangan pengetahuan para calon investor terutama mahasiswa terkait manfaat, keuntungan, kemudahan, prosedur, jenis instrumen investasi, persyaratan melakukan investasi saham atau obligasi di Pasar Modal.

JAS-PT

JURNAL ANALISIS SISTEM PENDIDIKAN TINGG ISSN $2580-5339$ elSSN $2620-5718$

Volume 3

Nomor 1

JULI 2019

Hal $31-52$

FORUM DOSEN INDONESIA 
2. Sinergitas Bursa Efek Indonesia dan Perguruan Tinggi termasuk Pemerintah diperlukan untuk pengembangan Galeri Investasi Perguruan Tinggi, terutama terkait Sarana Prasarana yang tidak murah.

3. Untuk penelitian selanjutnya, dapat dimasukkan aspek pengetahuan investasi lainnya yang dapat memperkuat dan memperkaya khasanah penelitian tentang investasi di Pasar Modal, antara lain Pengetahuan Informasi dan sumbernya yang mempengaruhi fluktuasi harga saham

\section{DAFTAR PUSTAKA}

Angelia, A., Wahyuningsih, D. and Herawati, H., 2019. Peranan Analisis Biaya Kualitas Dalam Meningkatkan Efisiensi Biaya Produksi. Jurnal IImiah Akuntansi Kesatuan, 7(1), pp.205212.

Baihaqi, M. 2016. Pengantar Psikologi Kognitif. Bandung: PT Refika Aditama.

Darmadji T., dan Fakhruddin, H. M. 2015. Pasar Modal di Indonesia. Jakarta: Salemba Empat.

Effendy, M., Surya, T.M. and Mubarak, M.M., 2009. Pengaruh Struktur Modal Terhadap Resiko Keuangan Perusahaan. Jurnal IImiah Kesatuan (JIK), 11(1).

Ferlina Arlin, Riswan Kuswardhana. 2017. Pengaruh Informasi Produk, Resiko Investasi, Kepuasan Investor dan Minat Mahasiswa Berinvestasi. Jurnal Sekretaris dan Administrasi Bisnis. Volume 1, Number 1, 2017. E-ISSN: 2580-8095.

[Kemenkeu RI], 2010. Master Plan Pasar Modal dan Industri Keuangan Non Bank 2010-2014. BAPEPAM LK Kementeria Keuangan Republik Indonesia

Komang Luh, I Putu Mega. 2015. Kemampuan Pelatihan Pasar Modal Memoderasi Pengaruh Pengetahuan Investasi Dan Penghasilan Pada Minat Berinvestasi Mahasiswa. Jurnal IImiah Akuntansi dan Bisnis, Vol. 10, No. 2, Juli 2015.

Halim, Abdul. 2015. Analisis Investasi di Aset Keuangan. Jakarta: Penerbit Salemba Empat

Hasan, Iqbal, 2005. Pokok - Pokok Materi Statistik 2. Cetakan ketiga, Jakarta : PT. Bumi Aksara.

Hermanto. 2017. Perilaku Mahasiswa Ekonomi di Universitas Esa Unggul Dalam Melakukan Investasi Di Pasar Modal. Jurnal Ekonomi, Volume 8, Nomor 2, Mei 2017.

Hidayat, L., Mulyana, M. and Effendy, M., 2018. Membangun Kepuasan Mahasiswa Pengguna Laboratorium Komputer. JAS-PT Jurnal Analisis Sistem Pendidikan Tinggi, 1(2), pp.93-101.

Mahardika, A.G., Pramiudi, U. and Fahmi, A., 2019. Peranan Penerapan Sistem Akuntansi Accurate Terhadap Penyusunan Laporan Keuangan (Studi Kasus Pada Umkm Toko Textile Leuwi Di Bogor). Jurnal IImiah Akuntansi Kesatuan, 7(1), pp.193-196.

Nurendah, Y., Mulyana, M. and Muanas, M., 2018. Evaluasi dan Pemetaan Minat Studi Siswa SMA dan SMK di Kota Bogor Pada Program Studi Ekonomi Syariah. JAS-PT Jurnal Analisis Sistem Pendidikan Tinggi, 2(2), pp.83-94.

JAS-PT

JURNAL ANALISIS SISTEM PENDIDIKAN TINGG

ISSN $2580-5339$

eISSN $2620-5718$

Volume 3

Nomor 1

JULI 2019

Hal $31-52$ 
Sugianto, D. 2017. Investor Aktif Pasar Modal Kini Didominasi Anak Muda. https://finance.detik.com/bursa-dan-valas/d-3426387/investor-aktif-pasarmodal-kini-didominasi-anak-muda (diakses pada 6 Agustus 2019 10:08 AM)

Suharyadi dan Purwanto, S. K. 2004. Statistika Dasar. Jakarta: Salemba Empat.

Sukartaatmadja, I., Thoyibah, H., Mulyana, M. and Yusdira, A., 2019. PELATIHAN DIGITAL LIBRARY BAGI PENGELOLA PERPUSTAKAAN PERGURUAN TINGGI SE-BOGOR.

Sulistiono, S., Nurendah, Y. and Mulyana, M., 2019. Mengukur Minat Studi Siswa SMA dan SMK di Kota Bogor Pada Program Studi Kewirausahaan. JAS-PT Jurnal Analisis Sistem Pendidikan Tinggi, 3(1), pp.1-12.

Syahyunan. 2013. Manajemen Keuangan. Medan: USU Press.

Verawati, Eka, 2014. Faktor-Faktor Penentu yang Mempengaruhi Return Saham Perusahaan Manufaktur Yang Terdaftar Di Bursa Efek Indonesia (BEI) Periode 2008-2013. Skripsi. Fakultas Ekonomi Universitas Negeri Yogyakarta 
JAS-PT

JURNAL ANALISIS SISTEM PENDIDIKAN TINGG

ISSN $2580-5339$

eISSN $2620-5718$

Volume 3

Nomor 1

JULI 2019

Hal $31-52$

FORUM DOSEN INDONESIA 